The University of Maine

\title{
DigitalCommons@UMaine
}

Marine Sciences Faculty Scholarship

School of Marine Sciences

$12-15-1998$

\section{Observations of the Eastern Maine Coastal Current and Its Offshore Extensions in 1994}

Neal Pettigrew

University of Maine - Main, nealp@maine.edu

David Townsend

University of Maine - Main, davidt@maine.edu

Huijie Xue

University of Maine - Main, hxue@maine.edu

J.P.Wallinga

P.J. Brickley

See next page for additional authors

Follow this and additional works at: https://digitalcommons.library.umaine.edu/sms_facpub

\section{Repository Citation}

Pettigrew, Neal; Townsend, David; Xue, Huijie; Wallinga, J. P.; Brickley, P. J.; and Hetland, R. D., "Observations of the Eastern Maine Coastal Current and Its Offshore Extensions in 1994" (1998). Marine Sciences Faculty Scholarship. 81.

https://digitalcommons.library.umaine.edu/sms_facpub/81 
Authors

Neal Pettigrew, David Townsend, Huijie Xue, J. P. Wallinga, P. J. Brickley, and R. D. Hetland 


\title{
Observations of the Eastern Maine Coastal Current and its offshore extensions in 1994
}

\author{
Neal R. Pettigrew, David W. Townsend, Huijie Xue, John P. Wallinga, \\ Peter J. Brickley, and Robert D. Hetland \\ School of Marine Sciences, University of Maine, Orono
}

\begin{abstract}
Cold surface temperatures, reflecting Scotian Shelf origins and local tidal mixing, serve as a tracer of the Eastern Maine Coastal Current and its offshore extensions, which appear episodically as cold plumes erupting from the eastern Maine shelf. A cold water plume emanating from the Eastern Maine Coastal Current in May 1994 was investigated using advanced very high resolution radiometer (AVHRR) imagery, shipboard surveys of physical and biochemical properties, and satellite-tracked drifters. Evidence is presented that suggests that some of the plume waters were entrained within the cyclonic circulation over Jordan Basin, while the major portion participated in an anticyclonic eddy at the distal end of the plume. Calculations of the nitrate transported offshore by the plume show that this feature can episodically export significant quantities of nutrients from the Eastern Maine Coastal Current to offshore regions that are generally nutrient depleted during spring-summer. A series of AVHRR images is used to document the seasonal along-shelf progression of the coastal plume separation point. We speculate on potential causes and consequences of plume separation from the coastal current and suggest that this feature may be an important factor influencing the patterns and overall biological productivity of the eastern Gulf of Maine.
\end{abstract}

\section{Introduction}

The Gulf of Maine is a midlatitude marginal sea that is bounded by the coastlines of New England, New Brunswick, and Nova Scotia. Along its "open" boundary with the North Atlantic, exchange is limited by the shoal regions of the Scotian Shelf, Browns Bank, Georges Bank, and Nantucket Shoals. At depths exceeding $100 \mathrm{~m}$, the exchange is confined essentially to the channels separating Georges and Browns Banks from the Scotian Shelf; the most significant of these is the Northeast Channel (Figure 1).

The relative isolation of the gulf from the open waters of the North Atlantic, together with significant input of fresh water from several large river systems including the St. John, the Kennebec/Androscoggin, and the Penobscot, produces some estuarine-like characteristics in the gulf circulation and property distributions [e.g., Hopkins and Garfield, 1979]. However, the freshwater budget for the Gulf of Maine is dominated by the inflow of relatively cold, low-salinity Scotian Shelf Water [Smith, 1983; Brown and Irish, 1993]. There is deep inflow of relatively high salinity slope water (SLW) through the Northeast Channel and compensating outflow of surface and intermediate waters

Copyright 1998 by the American Geophysical Union.

Paper number 98JC01625.

0148-0227/98/98JC-01625\$09.00 that occurs primarily on the southwestern side of the Northeast Channel and through the Great South Channel [Bigelow, 1927; Hopkins and Garfield, 1979; Brooks, 1985; Ramp et al., 1985]. Like other marginal seas and unlike archetypal estuaries, the gulf is large relative to its internal deformation radius $(10 \mathrm{~km}$ ) and thus supports mesoscale circulation features including a complex coastal current system.

Little is known in detail about the Gulf of Maine's coastal current system. There are generally thought to be two principal branches: the Eastern Maine Coastal Current (EMCC), identified with the cold coastal band that extends from the southwestern Scotian Shelf, across the mouth of the Bay of Fundy, and along the eastern coast of Maine to the vicinity of Penobscot Bay [Townsend et al., 1987; Brooks and Townsend, 1989; Bisagni et al., 1996]; and the Western Maine Coastal Current (WMCC), which extends from Penobscot Bay to Cape Cod, Massachusetts [Brooks, 1985] and is not easily identified by surface temperature patterns. The scientific consensus is that a portion of the EMCC turns offshore at a variable location east of Penobscot Bay, perhaps contributing to the cyclonic circulation in Jordan Basin, and that a portion continues on, feeding into the WMCC [Brooks, 1985; Brooks and Townsend, 1989]. It is unknown if there are times when the EMCC follows exclusively one route or the other.

Brooks and Townsend [1989] showed that the location of the coastal current's offshore retroflection can be 




Figure 1. Base map of the Gulf of Maine showing significant bathymetric features and coastal locations referred to in the text. Also shown are the three hydrographic lines (S1-S11, S11-S17, G1-G9) and the current meter mooring location (M1).

highly variable over periods of weeks during the summer season. Using satellite sea surface temperature (SST) images and successive hydrographic cruises in August 1987, they observed that the alongshore location of the separation point of the cold coastal plume progressed westward toward Penobscot Bay approximately $50 \mathrm{~km}$ over a 3-week period. They related this variation to the quantity and distribution of dense bottom waters within the Jordan Basin and suggested that southwestward propagation of the separation point might be an annual event as the deep Jordan Basin fills with slope water. The term "slope water steering" was used to describe the relationship between deep water distribution and the trajectory of the coastal plume.

Townsend et al. [1987] and Brooks and Townsend [1989] emphasized the importance of the coastal current system and its rich load of inorganic nutrients to the bi- ological productivity of the Gulf of Maine. Townsend et al. [1987], using conductivity-temperature-depth (CTD) surveys and measurements of phytoplankton chlorophyll and inorganic nutrients, argued that the cold coastal band found in eastern coastal Maine is primarily the signature of a tidal mixing plume that forms near Grand Manan Island and subsequently flows southwestward along the coast. They showed that the surface nutrient and surface temperature distributions are well correlated and suggested that this cold, high-nitrate plume is an important agent for transporting nutrients derived from tidal mixing of Jordan Basin water near Grand Manan Island, to the rest of the gulf. By this mechanism a local region of intense tidal mixing could influence downstream productivity, which in the case of the EMCC, potentially includes the entire coastal gulf and the interior of the eastern Gulf of Maine. 
Evidence of the nutrient-rich cold coastal current system dates back to Bigelow [1926], who noted the persistence of high densities of diatoms in a high chlorophyll region more recently described by Townsend et al. [1987]. Fish and Johnson [1937] described the cold water current in greater detail and plotted drift bottle tracks that are consistent with the notion of a plume separating from the coastal boundary and flowing offshore. Evidence of the biological influence of the offshore plume is reflected also in the work by Huntley and Boyd [1984], who studied data collected on ferry crossings from Portland, Maine, to Yarmouth, Nova Scotia. They noted that the cold surface signature was correlated with high phytoplankton chlorophyll and high zooplankton biomass and production.

Bisagni et al. [1996] investigated the temporal and spatial variability of Gulf of Maine SST through a 12month (1982) time series of 5-day-averaged, optimally interpolated advanced very high resolution radiometer (AVHRR) satellite images. Bisagni et al. [1996] report that the annual mean SST field shows a minimum or cold band extending along the coast from the vicinity of Cape Sable, Nova Scotia, to eastern coastal of Maine, as far southwest as the mouth of Penobscot Bay. However, separation of the cold plume from shore was not apparent in the annual mean distribution. This result suggests that although the cold coastal band is a persistent feature of the eastern Gulf of Maine, location of the plume separation from the coast was too variable to be clearly manifest in the annual mean SST picture. The frequency of occurrence of plume separation, plume subsurface structure, and the variability of the separation point remain issues about which little is known.

Recent numerical studies by Brooks [1994] have led him to suggest that the density front associated with the Penobscot River Plume may partially block and redirect the EMCC. Model runs showed a splitting of the EMCC such that an outer branch recirculated to the interior gulf (Jordan Basin) while the inshore branch meandered back toward the coast and fed the Western Maine Coastal Current. The same study also showed lesser deflection of the WMCC in the region of the Kennebec-Androscoggin River plume.

Lynch et al. [1997] investigated the Gulf of Maine coastal current system using a three-dimensional finite element numerical model nested within their coarserscale gulf-wide model [Lynch et al., 1996]. From preliminary dynamical analyses of the model output they concluded that barotropic inflow from the Scotian Shelf [Smith, 1983] and tidal rectification [Loder, 1980] are of primary importance in producing the EMCC. A more recent modeling study by Xue et al. [1996] highlights the connection between the EMCC and the Scotian Shelf inflow [Smith, 1983] and reproduces the qualitative features of the EMCC in the absence of tidal rectification processes.

Two simulations by Lynch et al. [1997] using regional hydrographic climatology for early spring (March/April) and early summer (May/June) periods show substantial differences. Under early spring climatological conditions, the model produces a coastal current with a large meander that appears south of Penobscot Bay, while under more strongly stratified summer conditions the meander is absent. These results suggest that the occurrence of the meander may be controlled in large part by the interplay of local bottom topography and density field.

We present here hydrographic and nutrient data from survey transects across several prominent cold plume features, extending from the EMCC into the interior of the eastern Gulf of Maine, that appeared in AVHRR imagery of the Gulf of Maine on May 11, 1994. Principal objectives of the work were to document the subsurface structure of these features, to estimate the associated nitrate flux from the coastal region into the interior of the Gulf of Maine, and to determine to what extent plume waters may be entrained into the cyclonic circulation of the Jordan Basin Gyre. We use satellitetracked drifters to help assess the degree of entrainment by the gyre and present supporting evidence from an additional hydrographic survey and moored current observations in the coastal current upstream of the location of the plume's separation from the shelf. We also investigate the persistence and evolution of the plume and its point of separation from the shelf during 1994 through a series of SST images.

\section{Data and Methods}

The primary hydrographic data used in this work were collected aboard the R/V Columbus Iselin during May 12-14, 1994. This brief survey, organized in response to an AVHRR SST image showing welldeveloped temperature structure in the eastern Gulf, was appended to a survey of Georges Bank [Townsend et al., 1994]. A total of 17 hydrographic casts were completed. Stations S1-S11 are along a line running from Boothbay Harbor to the central Jordan Basin, and S11-S17 form a second line extending from Jordan Basin across Truxton Swell and Georges Basin to the northern edge of Georges Bank (Figure 1). A Neil Brown MKIII CTD with a SeaTech in situ fluorometer provided profiles of temperature, salinity, density, and chlorophyll fluorescence. Water samples were collected at five-seven depths at stations S1-S11 using a General Oceanics rosette sampler. The sampling depths, which varied from station to station depending upon density structure and total water column, are noted on Figure 5a. The water samples were analyzed for dissolved inorganic nitrogen (nitrate plus nitrite) using a semiautomated nutrient analyzer and for concentrations of phytoplankton chlorophyll a, determined fluorometrically on $100 \mathrm{~mL}$ samples collected on glass fiber filters [Parsons et al., 1984]. Nutrient and chlorophyll measurements were not obtained for stations S12-S17 (transect 2). 


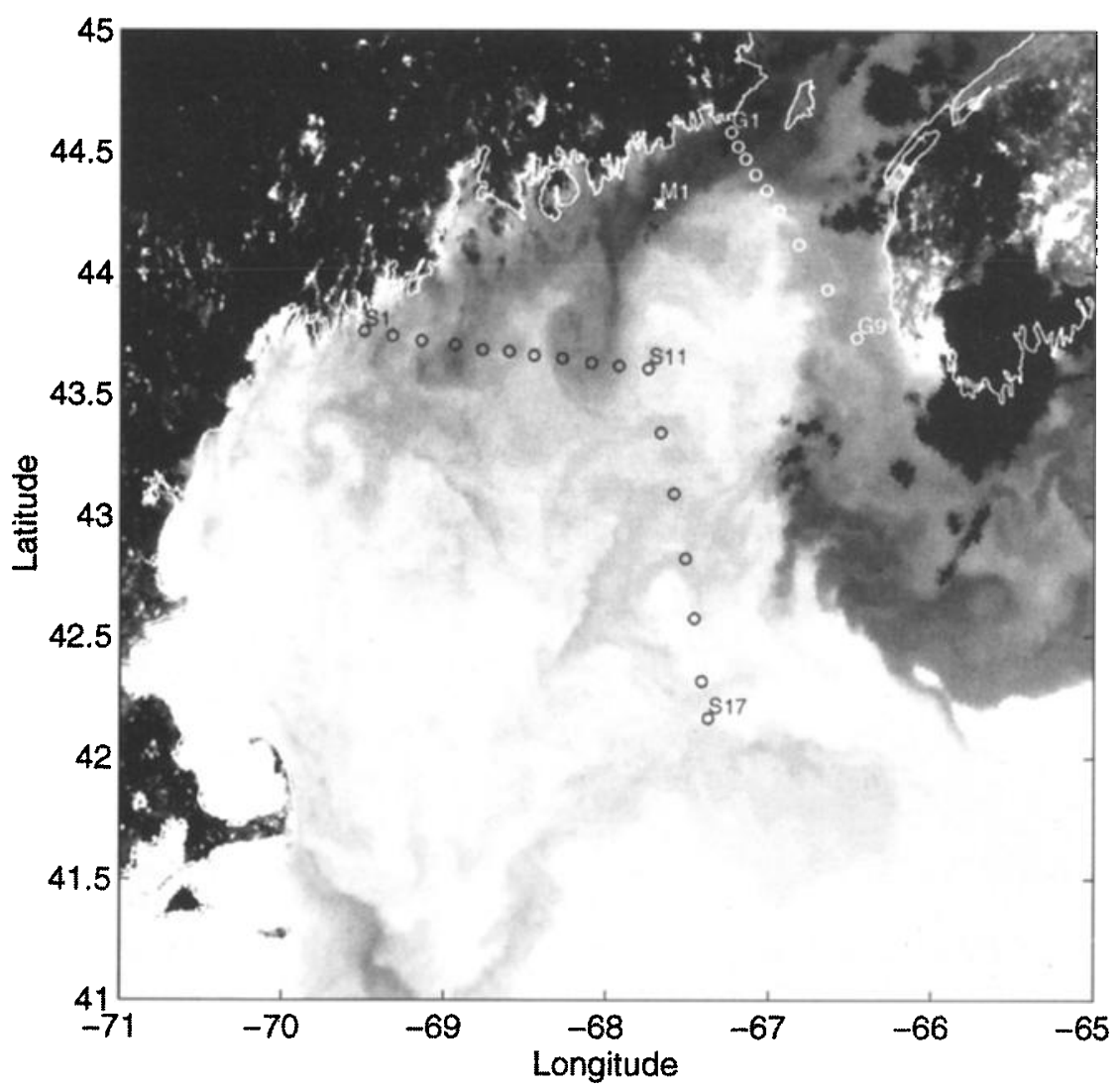

Figure 2. Satellite-derived sea surface temperature (SST) for May 11, 1994, 0900 UT, obtained from the National Oceanic and Atmospheric Administration Coastwatch program. The image resolution is approximately $1.4 \mathrm{~km}$, the temperature scale ranges from $<5.5^{\circ} \mathrm{C}$ (black) to $>8.5^{\circ} \mathrm{C}$ (white), and the coastline is outlined in white. A cold (dark) coastal band extends from the Scotian Shelf, through the Bay of Fundy, and along the eastern coast of Maine. Near Schoodic Point a portion of the cold coastal band separates from the shelf and forms an anticyclonic eddy south of Mount Desert Island. Locations of the coastal mooring (M1) and the hydrographic stations from the surveys of May 12-14, 1994 (S1-S17) and April 28, 1994 (G1-G9), are overlain on the SST image.

CTD casts from a third hydrographic line (stations G1-G9) were obtained as part of a large-scale survey of the eastern Gulf of Maine during the period April 26-29, 1994, 2 weeks prior to the May survey. During the April survey aboard the R/V ARGO-Maine, the ship's main CTD and rosette sampler malfunctioned. Hydrographic data were therefore collected with a Sea-Bird Sealogger 25 , and no water samples were obtained.

Satellite-derived SST images used in this study were provided by NOAA Coastwatch. The data were processed using multichannel, atmospherically corrected algorithms developed by NOAA and had a resolution of approximately $1.4 \mathrm{~km}$.

Ancillary data on flow conditions were obtained from an acoustic Doppler current profiler (ADCP) moored in the coastal current (location M1, Figure 2) and from satellite-tracked drifters released in Jordan Basin.

\section{Results}

Figure 2 shows an AVHRR satellite SST image of the Gulf of Maine from May 11, 1994. The principal feature of the image is a band of cold surface temperature that appears on the Nova Scotian Shelf (both inside and outside the confines of the gulf) and along the coastline of eastern Maine. The coldest surface waters appear in a band roughly $30 \mathrm{~km}$ wide along the Maine coast, from Grand Manan Island to Schoodic Point, just east of Mount Desert Island. The cold surface temperatures observed in this region $\left(4-5^{\circ} \mathrm{C}\right)$ are, at least in part, a consequence of the vigorous tidal mixing that occurs in the vicinity of Grand Manan Island [Garrett et al., 1978; Loder and Greenberg, 1986) and subsequent advection southwestward [Townsend et al., 1987]. The lateral density gradients associated with the vertical mix- 

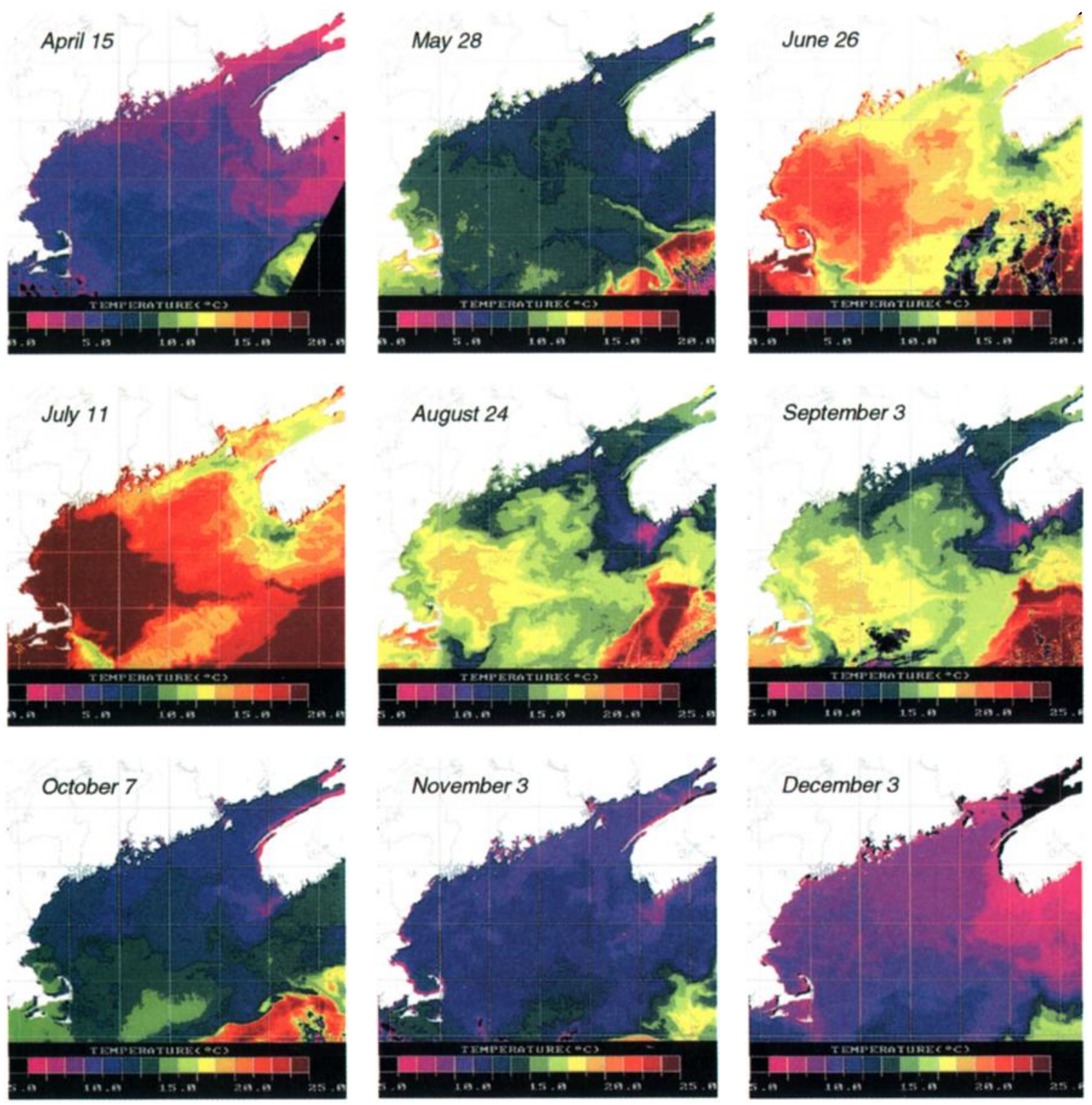

Plate 1. A series of one SST image per month from April through December 1994. The images, chosen on the basis of image clarity, show seasonal variations in the location of separation of the plume from the coastal current.

ing would contribute to the downcoast advection [see Pettigrew and Murray, 1986], as would the forcing associated with fresh coastal runoff.

At Schoodic Point a large portion of the cold coastal surface water separates from the shelf and extends approximately $50 \mathrm{~km}$ southward along the western side of the Jordan Basin (Figure 2). SST values of the offshore plume are up to $1^{\circ} \mathrm{C}$ warmer (lighter gray in Figure 2) than the waters of its coastal current origin, and the SST patterns suggest that the terminal bolus has anticyclonic vorticity. A second offshore-directed cold plume extends south-southwest from the mouth of Penobscot Bay, the region commonly identified in the literature as the typical separation point of the cold coastal band during the spring and summer seasons. Another segment of the coastal SST minimum extends to the southwest beyond Penobscot Bay into the western Gulf of Maine, the last vestiges of the which are visible south of the mouth of the Androscoggin/Kennebec River system in a group of cold filaments. Careful inspection of Figure 2 reveals a rich texture of additional surface temperature variability in the eastern and central gulf, including a diffuse cool surface feature that appears to extend from the Scotian Shelf southwestward along the Truxton Swell.

Our survey of the satellite images for 1994 shows that the cold coastal band is identifiable from April through November in all clear images of the gulf and 
that some form of plume separation is generally observed, although the plume morphology and separation point are quite variable. With the exception of the winter season (December, January, and February), when no significant temperature contrasts are observed between the Maine coastal waters and the central gulf, the cold band is narrowest and the SST gradients strongest along the eastern Maine coast (Plate 1).

The sequence of images in Plate 1 shows a seasonal oscillation of the alongshore location of the separation point. In mid-April there were two offshore plumes or branches of the EMCC, both of which separated from the coast east of Penobscot Bay and showed anticyclonic terminal "hooks." By late summer/early fall the separation region or branch point had moved well west of Penobscot Bay and the plume showed strong cyclonic curvature. As late fall approached, the separation point retreated back to the region east of Penobscot Bay. This seasonal variability suggests that the strength of the density stratification may play an important role in determining where the coastal current separates from the coast.

\subsection{Hydrographic Conditions Along Transect 1 (May 12-13)}

Temperature, salinity, and $\sigma_{t}$ sections along transect 1 are shown in Figures 3a-c. The transect extends from midcoast Maine to the central Jordan Basin and cuts across the two main cold surface features identified in Figure 2, the plume extending offshore from the mouth of Penobscot Bay, and the eddy-like distal end of the plume extending southward from Schoodic Point.

While the AVHRR image (Figure 2) shows that the SST minimum off Schoodic Point (S9) is the more sharply defined of the two low-temperature features, it is in the subsurface hydrographic structure that the major differences are seen. The plume originating at Schoodic Point appears in cross section as an intrusion of relatively fresh coastal water into the interior gulf. The feature has a lateral scale of roughly $40 \mathrm{~km}$, and its cold core (defined here as $\mathrm{T}<5.5^{\circ} \mathrm{C}$ ) extends to roughly $110 \mathrm{~m}$ depth, with distortion of the underlying isotherms occurring throughout the water column.

In contrast, inshore stations (S1-S4) reveal that the cold feature observed over the shelf has distinct characteristics that are confined to the upper $20 \mathrm{~m}$. The low surface salinity values argue that this feature is the outflow plume from the Penobscot River that has overridden an inner branch of the coastal current that continued to flow southwest along the coast without significant separation. This result shows that caution needs to be exercised when interpreting SST features in the vicinity of the Penobscot River as evidence of an offshore trajectory or meander of the coastal current. The

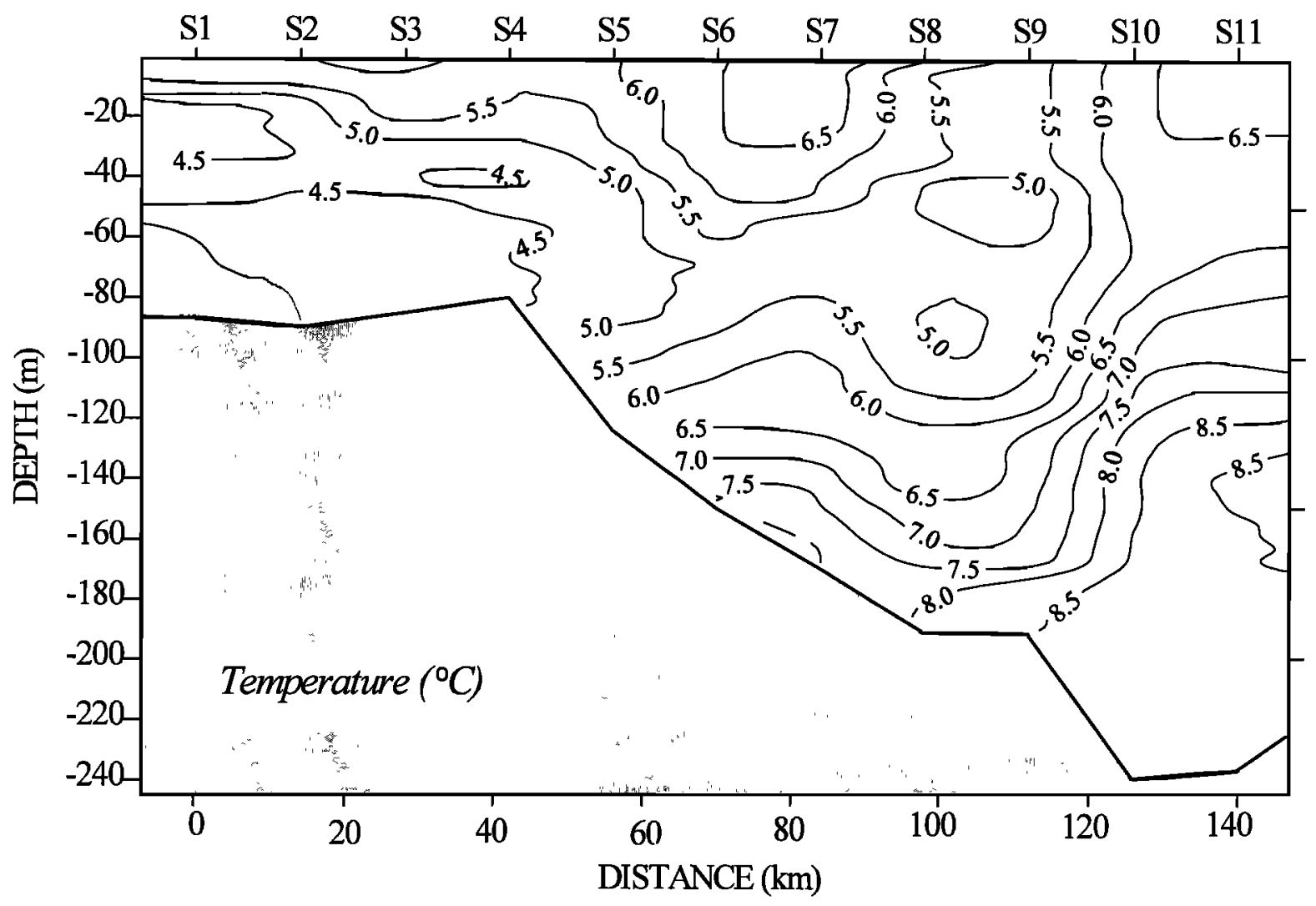

Figure 3a. Temperature contours along hydrographic transect 1. The inshore (S1-S5) and offshore (S8 and S9) branches of the cold coastal current show clearly in the hydrographic section as subsurface cold cores. In the offshore branch (plume eddy), distortions of the underlying temperature distribution associated with the middepth cold core extend to the bottom. 




Figure 3b. Salinity contours along hydrographic transect 1 . The retrograde salinity distribution over the shelf region is typical of a buoyancy-driven coastal current. The apparent source of the low-salinity lens in the upper $20 \mathrm{~m}$ of the shelf is the Penobscot Estuary. The plume at S8-S9 appears as relatively fresh coastal values embedded in the offshore regime. Beneath the plume, eddy slope water levels, indicated by salinities greater than 34 , are depressed.

features may instead reflect the local outflow of the estuarine plume.

The hydrographic distributions shown in Figures 3a-c reveal several other interesting features. Below the estuarine outflow plume, the shelf region is characterized by a retrograde salinity distribution, characteristic of a modest, downcoast, runoff-driven current. The salinity and temperature distributions over the shelf tend to compensate one another so that the isopycnals are relatively flat over the lower $50-60 \mathrm{~m}$ of the shelf water column. Farther offshore, centered on stations S8 and S9, low salinity water $(<32.4)$ extends down to 80 $\mathrm{m}$, with distortions of the underlying salinity distribution evident to the bottom (190 m). The hydrographic structure is consistent with an anticyclonic eddy or meander, as also suggested by the SST pattern in Figure 2. The offshore edge of the eddy feature coincides with the shoreward edge of a steep density gradient associated with a cyclonic circulation around the central Jordan Basin. At stations S10 and S11 the depth of the 34 isohaline, which serves as a convenient indicator of slope water, is roughly $100 \mathrm{~m}$; at stations S8 and S9 the 34 isohaline is at $175 \mathrm{~m}$; and at station $\mathrm{S} 6$ it has risen again to approximately $140 \mathrm{~m}$ depth. Thus the plume appears embedded in a low in the slope water topography, sug- gesting that the offshore intrusion of coastal current has locally depressed the slope water topography.

Geostrophic calculations using a 140 dbar reference level confirm that the cold core eddy centered at station $\mathrm{S} 9$ is an anticyclonic feature and suggest that associated surface current speeds exceed $0.3 \mathrm{~m} \mathrm{~s}^{-1}$ (Figure 4). These geostrophic calculations also provide a velocity scale for the cyclonic Jordan Basin Gyre. Assuming that the boundary between the eddy and the Jordan Basin Gyre is between stations S10 and S11, the velocity scale of the Jordan Gyre is approximately $0.1 \mathrm{~m} \mathrm{~s}^{-1}$.

\subsection{Biological Significance to the Plume}

The EMCC plume is of biological significance because it contributes to an offshore nutrient flux at a time of the year when offshore surface waters would otherwise be depleted of nutrients. As shown in Figure 5a, a relatively high surface concentration of $\mathrm{NO}_{2}+\mathrm{NO}_{3}$ ( $\sim 8 \mu M \mathrm{~N}$ ) was observed at station $\mathrm{S} 9$, located within the core of the plume (see Figure 2). The new nitrogen $\left(\mathrm{NO}_{2}+\mathrm{NO}_{3}\right)$ flux associated with the plume can be estimated using the calculated geostrophic currents (Figure 4) and the $\mathrm{NO}_{2}+\mathrm{NO}_{3}$ concentration between 


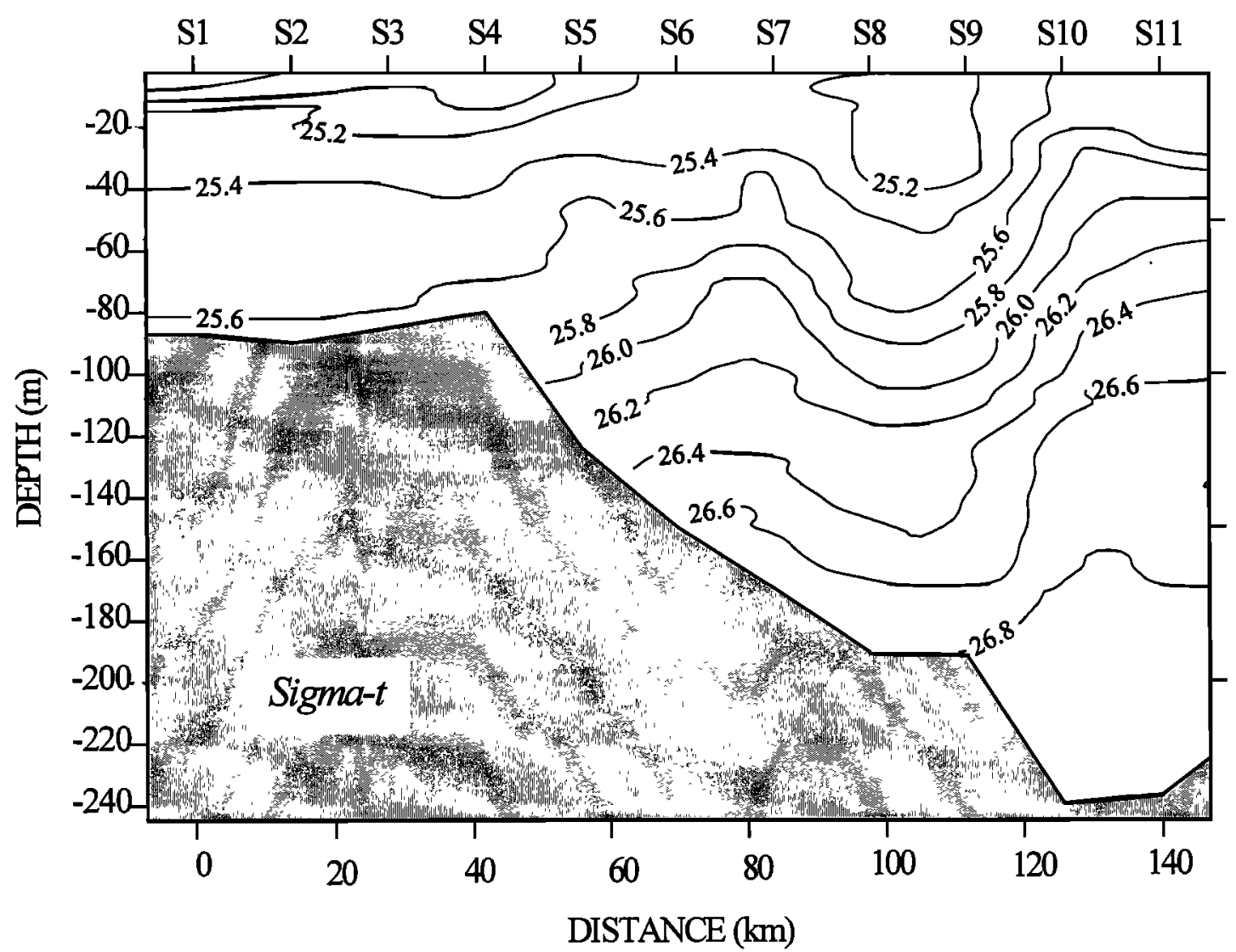

Figure 3c. The $\sigma_{t}$ contours along hydrographic transect 1 . The density field is corresponding to the T-S distribution. The structure of the plume at S8-S9 is consistent with anticyclonic vorticity as also suggested by the SST pattern observed in Figure 2.

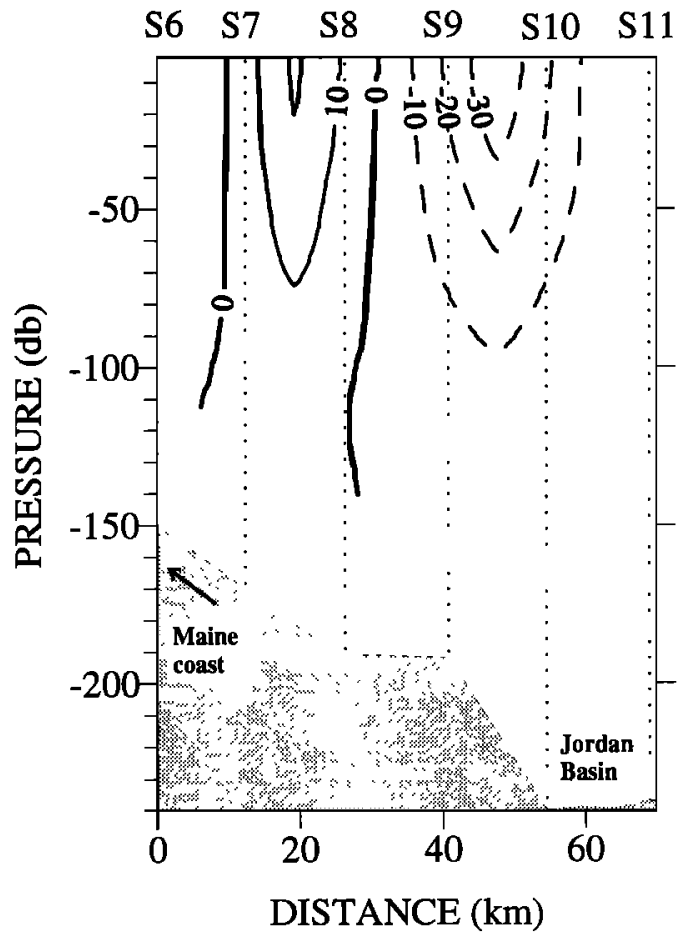

stations S8 and S10 (Figure 5a). Using a trapezoidal numerical integration over the upper $90 \mathrm{~m}$, we arrive at a flux of approximately $5 \mathrm{~kg} \mathrm{~N} \mathrm{~s}^{-1}$. This nitrate flux is of the same order as both the flux estimated by Townsend et al. [1987] for the coastal current in the vicinity of Grand Manan Island and the influx through the Northeast Channel estimated by Schlitz and Cohen [1984]. The kinematics of the plume thus take on great potential biological significance because of its episodic and spatially variable nature. Variability in the magnitude, direction, and location of this high-nutrient flow could result in alteration of the type and magnitude of primary production in the western, central, and eastern Gulf of Maine.

Figure 4. Geostrophic velocity, contoured in centimeters per second, relative to a $140 \mathrm{dbar}$ reference level along transect 1 from station S6-S11. Solid contours indicate flow inward approximately in the northward direction. The calculations support the view, suggested by the SST image, that the plume possesses strong anticyclonic vorticity. 


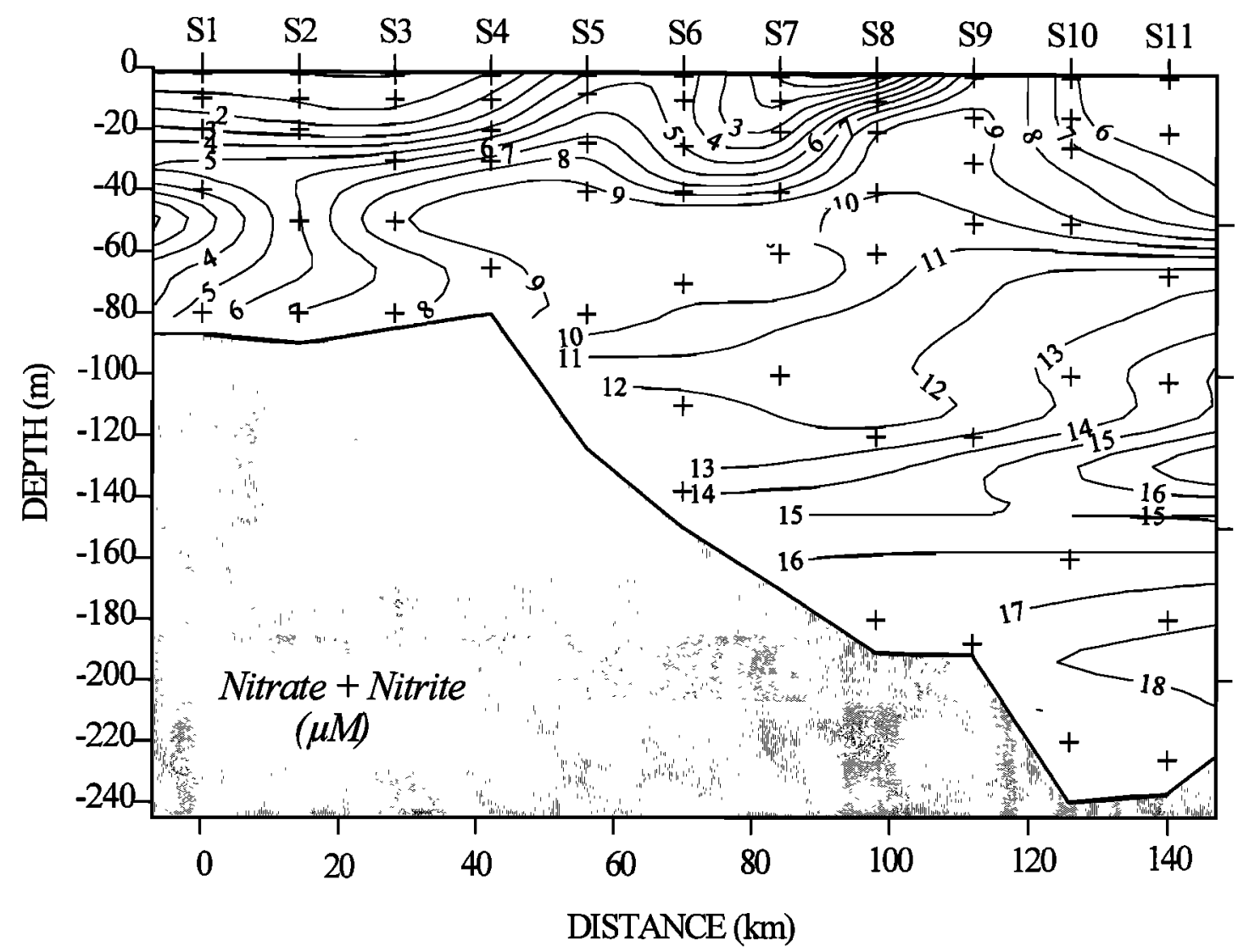

Figure 5a. Contours of nitrate $\left(\mathrm{NO}_{3}\right)$ plus nitrite $\left(\mathrm{NO}_{2}\right)$ in $\mu \mathrm{M}$ along transect 1 running from the central Maine coast to the central Jordan Basin. Highest near-surface values occur between stations S8 and S10, within the offshore plume.

The accompanying chlorophyll distribution (Figure $5 \mathrm{~b})$ shows that high chlorophyll concentrations are found only in the upper $20 \mathrm{~m}$ of the first seven stations and not in the high-nutrient waters within the cold plume core. These low chlorophyll values suggest that the nutrients, recently exported from the tidal mixing region along the eastern Maine coast, had not yet been utilized.

\subsection{Hydrographic Conditions Along Transect 2 (May 13-14)}

The hydrographic sections (transect 2) extending from the central Jordan Basin to the northern flank of Georges Bank are shown in Figures 6a-c. While this transect is devoid of the sharply defined SST structure that characterized transect 1 , the subsurface temperature distribution (Figure 6a) shows clearly a cold core $\left(<5.5^{\circ} \mathrm{C}\right)$ between stations 12 and 13 , centered at essentially the same depth at which it appeared at stations S8 and S9. Although the cold core is a very prominent feature of the subsurface hydrography, it does not have an extensive surface expression. There is a thin filament, visible near S12 in Figure 2, that appears to extend cyclonically from the plume eddy, suggesting that some of the coastal current plume was entrained into the southern limb of the Jordan Basin Gyre. Other surface filaments that are observed farther to the south extend along the shallower portions of the Truxton Swell and appear to be connected to the Scotian Shelf.

The salinity values associated with the cold core along this section are significantly higher than those observed at stations $\mathbf{S 8}$ and $\mathbf{S} 9$ of transect 1 . In this experiment, salinities less than 32.4 indicated coastal current waters. Since the salinity of the cold core on transect 2 exceeded this value, it is clear that this feature is not simply an extension of the cold plume around Jordan Basin but, rather, a mixture that includes waters of higher salinity.

As was observed in transect 1 , the cold core water occupies a low in the slope water topography (Figures 6a and $6 \mathrm{~b}$ ). The 34 isohaline at station 14 in the Crowell Basin (the northern extension of Georges Basin) occurs at a very shallow $63 \mathrm{~m}$ depth, while over the northern flank of Truxton Swell it dips to approximately $160 \mathrm{~m}$ and then rises again to roughly $100 \mathrm{~m}$ in the central Jordan Basin (S11). These slope water distributions are consistent with distinct cyclonic circulation cells over the Jordan and Georges Basins [see Brooks, 1985; Pet- 


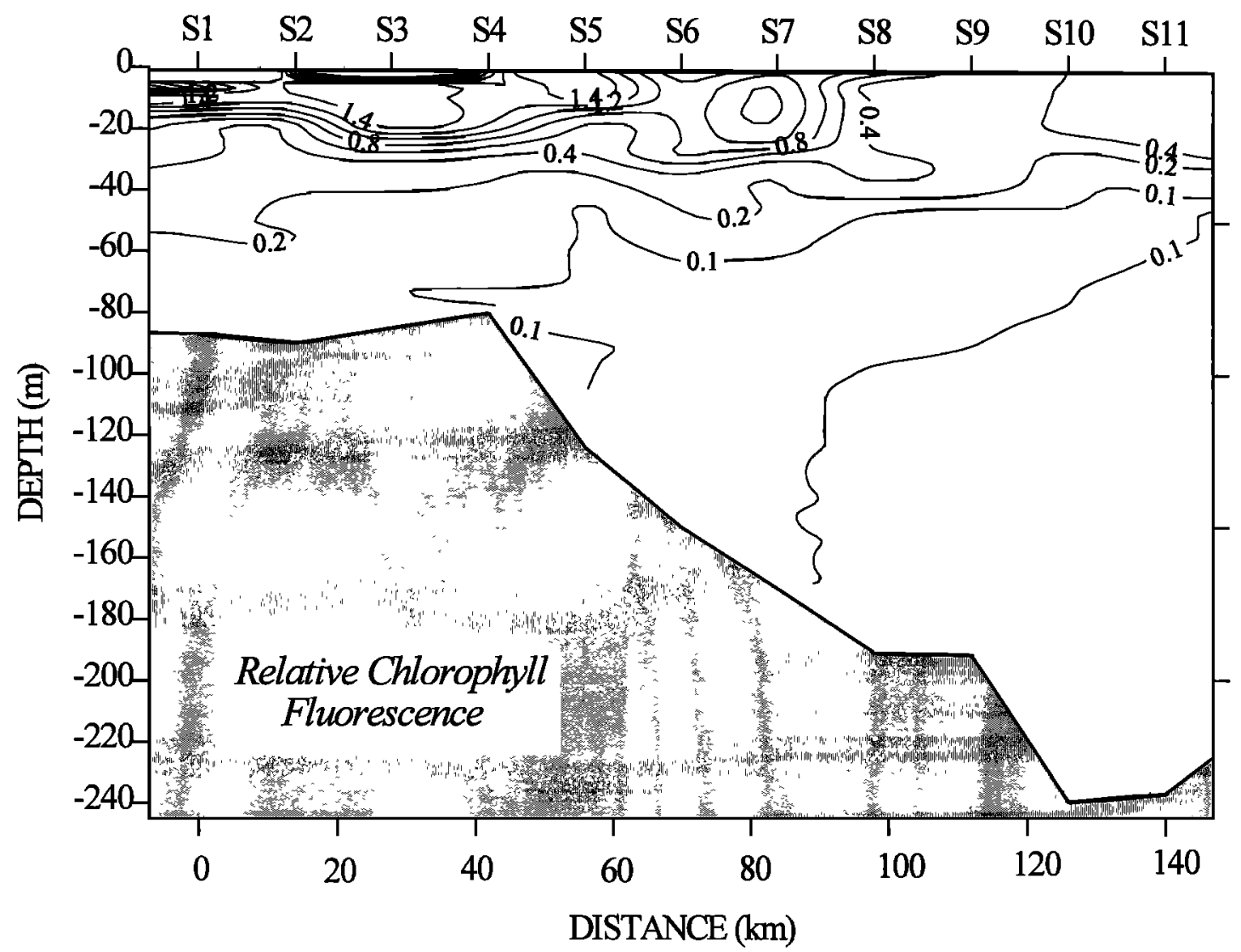

Figure 5b. Contours of relative fluorescence from in situ fluorometer profiles. High-chlorophyll fluorescence is indicated on the warm edges of the plume, while within the plume itself, values are low.

tigrew and Hetland, 1995], with a strong anticyclonic shear zone occurring at the boundary between the two gyres over the Truxton Swell. This strong lateral shear is reflected in Figure 7, which shows geostrophic currents calculated relative to the $140 \mathrm{dbar}$ level. There is a geostrophic flow of approximately $0.06 \mathrm{~m} \mathrm{~s}^{-1}$ eastward along the northern flank of Truxton Swell that is interpreted as the recirculation of the southern edge of the Jordan Basin Gyre and a westward flow with peak surface speeds of $0.17 \mathrm{~m} \mathrm{~s}^{-1}$ over the top of Truxton Swell.

Direct evidence of cyclonic circulation within Jordan Basin is provided by satellite-tracked drifter ( 40 $m$ drogue depth) trajectories, which have been superimposed on a second May 11 SST image in Figure 8. Together, the two drifters show a cyclonic displacement around the central Jordan Basin with drifter speeds of the order of $0.1 \mathrm{~m} \mathrm{~s}^{-1}$. The more southern of the two drifters shows a trajectory from the edge of the coastal current plume eastward across the southern Jordan Basin. These data suggest that some plume waters are entrained into the Jordan Basin Gyre.

\subsection{Hydrographic Conditions Along Transect 3 (April 28)}

A hydrographic survey carried out April 26-29, 1994, included stations G1-G9 running southeastward from just southwest of Grand Manan Island across the entrance of the Bay of Fundy (hereinafter referred to as the Fundy Channel) to the southwestern Scotian Shelf (Figure 1). On the Nova Scotian side of the transect, the temperature and salinity distributions show a retrograde front between G7 and G8 separating a relatively homogeneous mass of Scotian Shelf Water from the warmer saltier waters in the Fundy Channel (Figures $9 \mathrm{a}$ and $9 \mathrm{~b}$ ). Although small quantities of slope water $(S>34.0)$ are occasionally found within the channel, none was present during this early spring survey period.

On the Maine side of transect 3 , nearly vertically homogeneous conditions were observed within $30 \mathrm{~km}$ of the coastline. These well-mixed conditions are consistent with the observations of Townsend et al. [1987] and the numerical predictions of Loder and Greenberg [1986], who noted that tidal mixing is strong enough in this region to prevent the seasonal development of vertical stratification. However, the fact that the well-mixed waters are colder and fresher than those immediately offshore shows that local tidal mixing is not the principal reason for the occurrence of the cold coastal band as suggested by Townsend et al. [1987]. If local mixing were the fundamental agent determining the surface water properties in the coastal current, one might expect it to be colder and saltier than the surface waters offshore of the mixed region. If, on the other hand, 


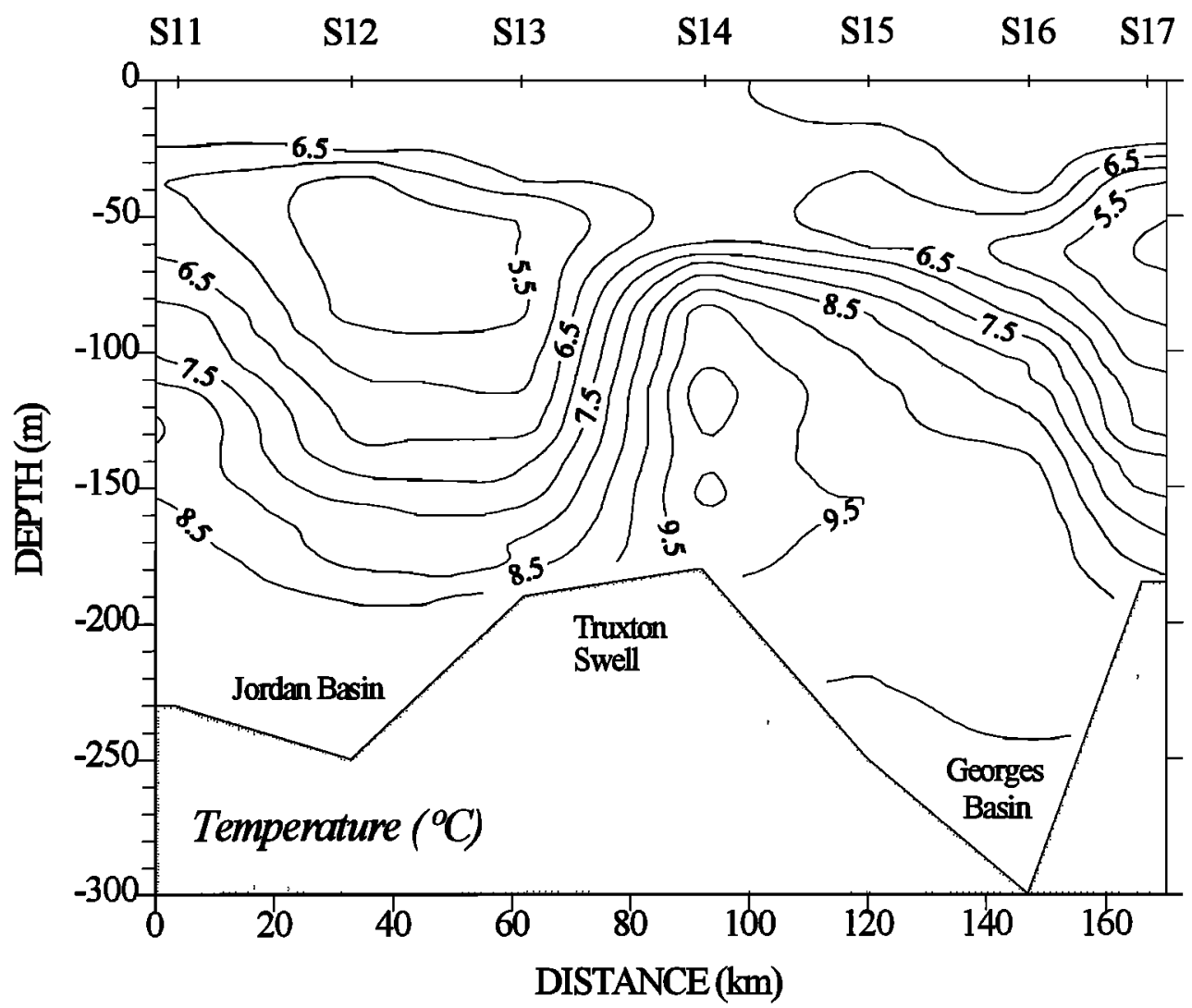

Figure 6a. Temperature contours along transect 2. A subsurface cold core is shown on the northern flank of the Truxton Swell between stations S12 and S13. The feature is similar in temperature, cross-sectional area, and depth of the temperature minimum to the plume seen in transect 1.

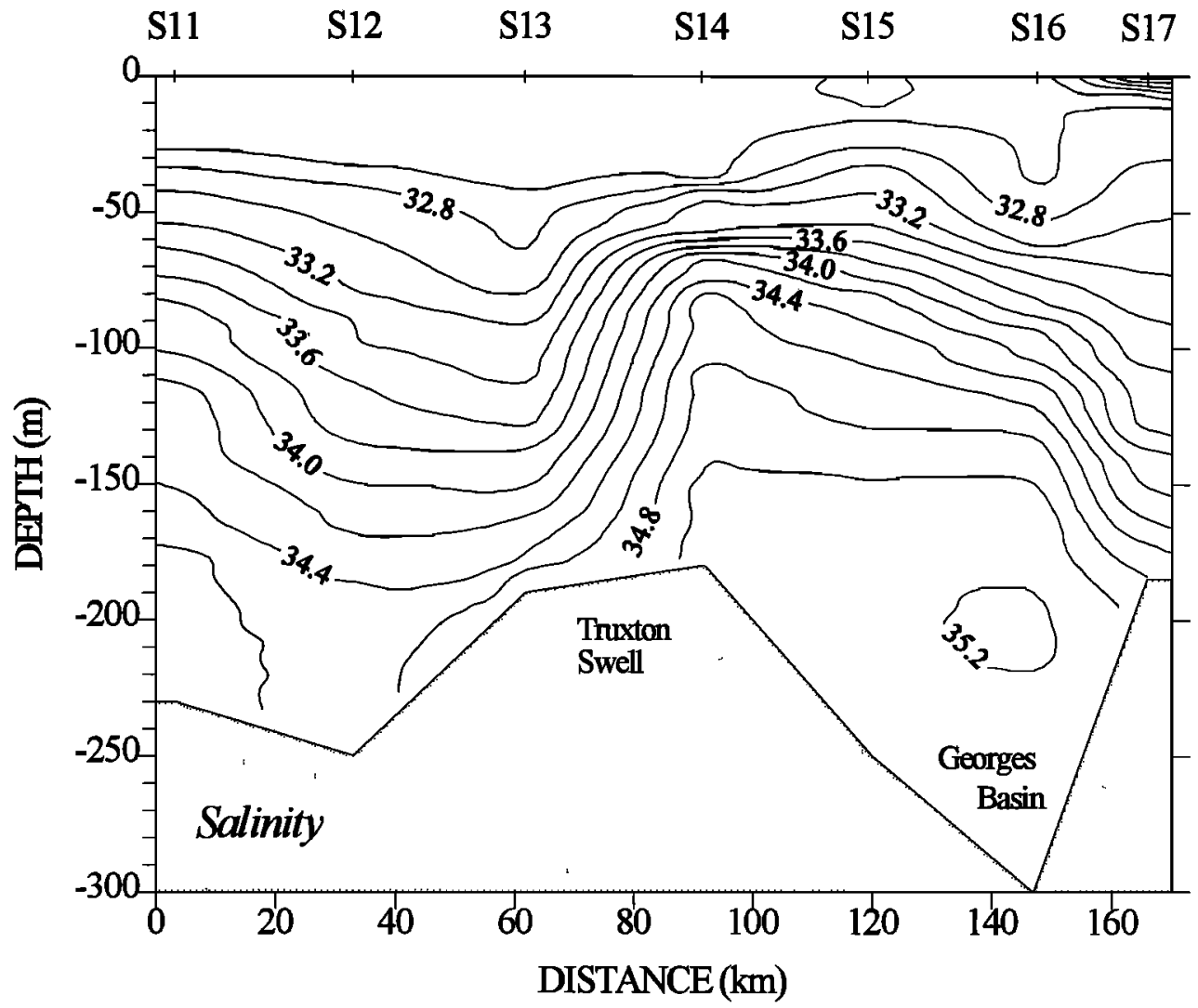

Figure 6b. Salinity contours along transect 2 . Salinity values associated with the cold core at S12-S13 are relatively fresh but significantly higher than those characterizing coastal current water. Note that the cold core occupies a low in the slope water topography as indicated by the 34 isohaline. 


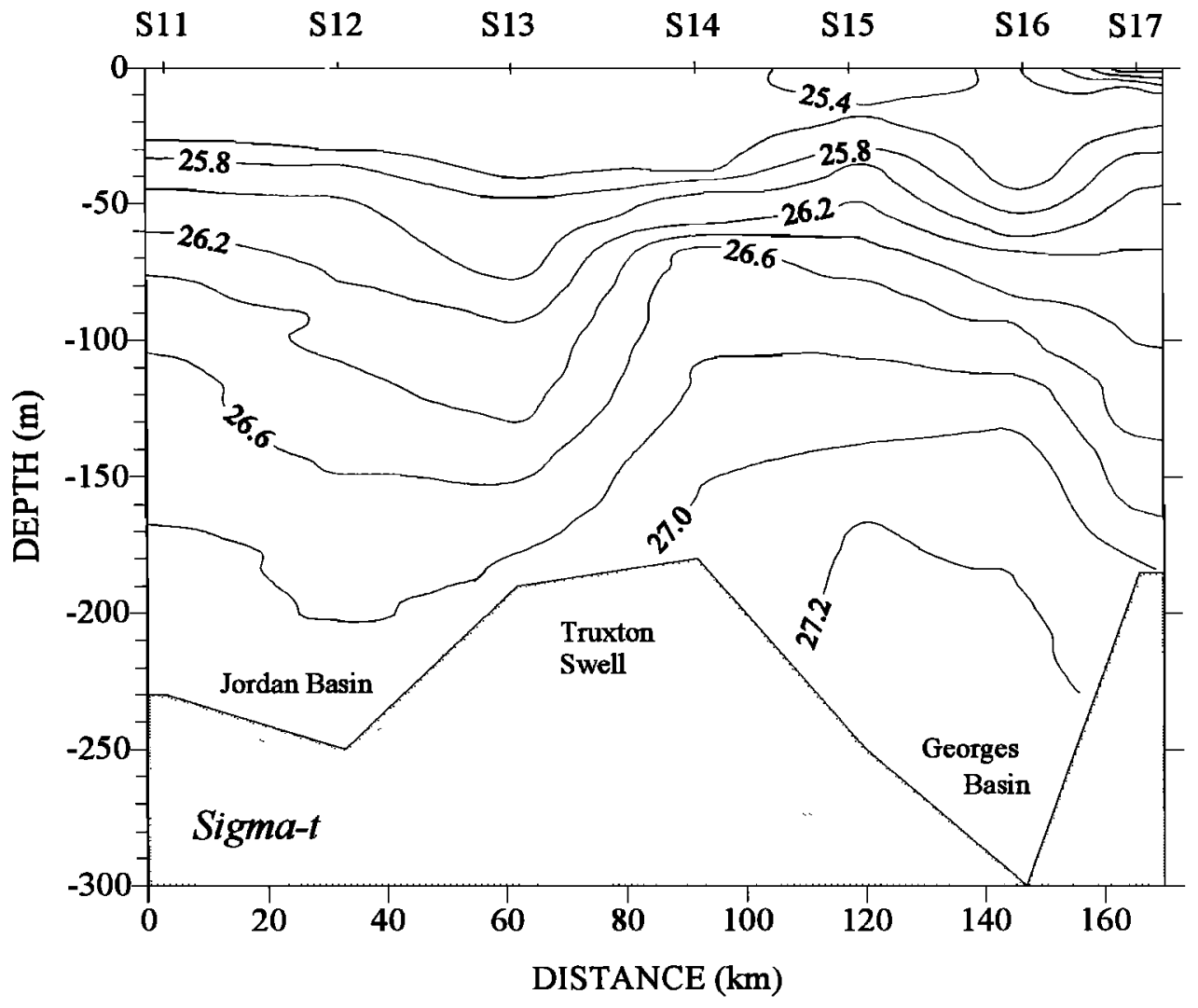

Figure 6c. The $\sigma_{t}$ contours along transect 2. Sigma-t contours reflect the large slope water dome within Georges Basin, the slope water trough over the northern flank of Truxton Swell, and the dome in the central Jordan Basin. The distribution is consistent with separate cyclonic gyres over the Jordan and Georges Basins.

the plume were restirred SSW that had been advected in the eastern side of the Bay of Fundy and back out the western side, its properties would be essentially the same as those observed on the east side of the transect. While the Maine coastal water's salinity is consistent with this scenario, its temperature is significantly colder than the SSW at G8 and G9. Figure 9a also shows a strong offshore temperature gradient with the temperature increasing from approximately $3.5^{\circ} \mathrm{C}$ near shore to $5^{\circ} \mathrm{C} 30 \mathrm{~km}$ farther from shore.

The source of this very cold water is revealed in the satellite image from April 15 (see Plate 1). The coldest SSTs in the gulf occur in a continuous band from the northwestern coastline of the Bay of Fundy, past Grand Manan, and along the coast of eastern Maine. The apparent continuity between the innermost waters of the EMCC and the western side of the Bay of Fundy appears not to persist through the warmer, more stratified months of May-September (Plate 1). During this period there is a large local maximum in the regional SST field that occurs between Grand Manan Island and the mouth of the St. John River, and there is visual continuity between the cold waters of the Scotian Shelf and those of the eastern Maine coast. Whether or not these patterns may be legitimately interpreted as indicative of flow continuity, thus implying that the immediate source region of the EMCC changes from early spring to summer, remains an open question. However, the SST patterns suggest that this may be the case.

\section{Discussion and Conclusions}

The Eastern Maine Coastal Current is associated, in spring, summer, and fall, with a continuous region of relatively low SST over the shelf regions of southwestern Nova Scotia and eastern Maine. This band of low coastal SSTs was discernible, April-November, in all cloud-free AVHRR images of the eastern Gulf of Maine in 1994. During the December-March period, no significant differences between the coastal and offshore SST were observed. A hydrographic section (G1-G9) from just west of Grand Manan Island to the southwestern Scotian Shelf and an AVHRR image (Plate 1) provide strong evidence that during early spring the source of the coldest waters along the eastern Maine inner shelf is the northwestern coastal boundary layer of the Bay of Fundy. However, this pathway appears to be closed off during the summer months when the outer Bay of Fundy exhibits a local surface temperature maximum. The region of high surface temperature occurs over the deepest part of the bay, where tidal mixing is insufficient to vertically mix a relatively fresh surface lens 


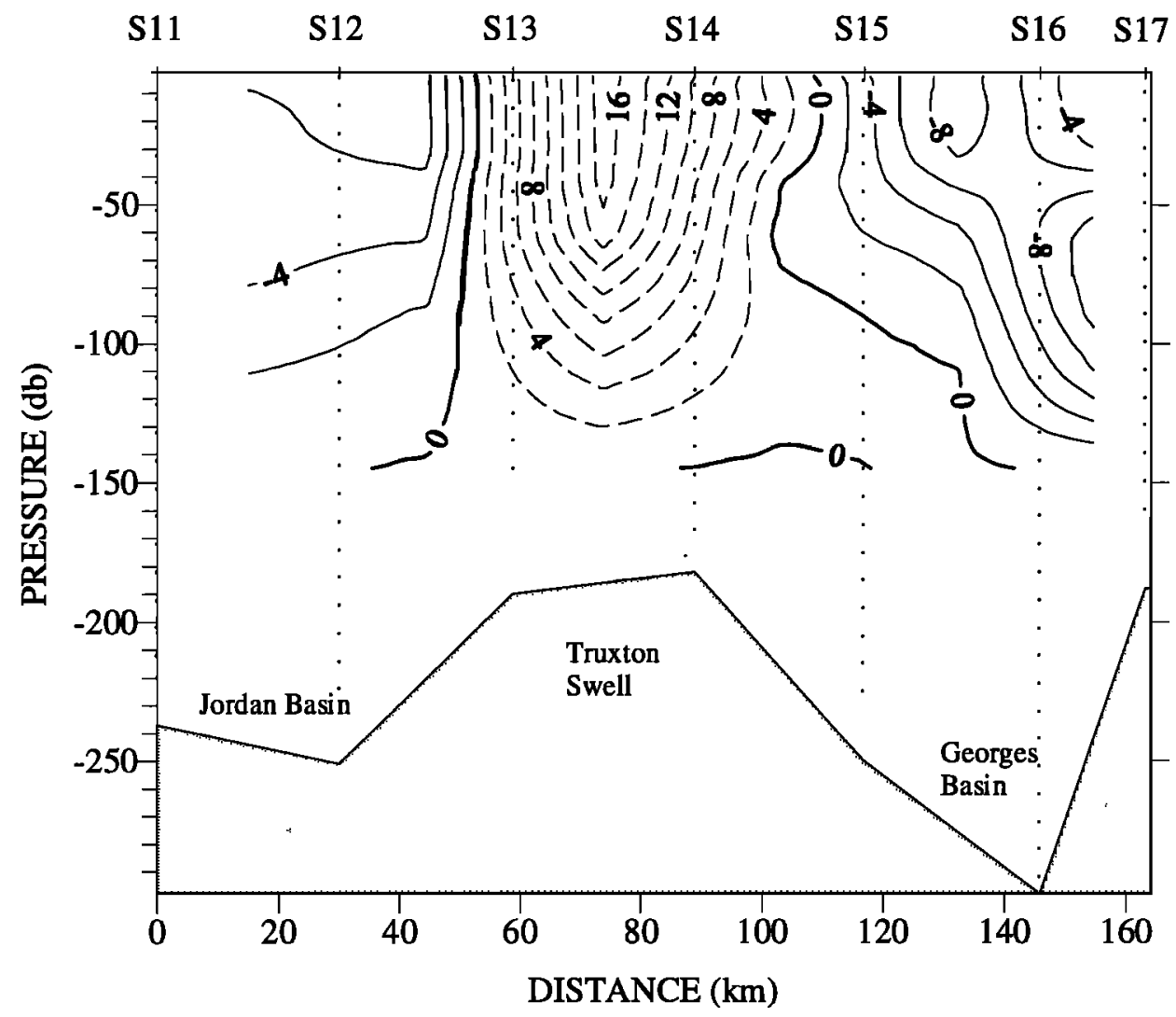

Figure 7. Geostrophic flow relative to the $140 \mathrm{dbar}$ reference level along transect 2 from stations S11 to S17. Solid contours indicate flow approximately eastward, and dashed contours represent westward flow. The strongest flow in the section is westward over the top of Truxton Swell. Over the northern flank of the Truxton Swell flow, in the location of the cold fresh core, the flow is eastward and is consistent with a cyclonic circulation around Jordan Basin.

associated with discharge from the St. John River and solar warming occurs more rapidly [Brooks and Gottlieb, 1985; Brooks, 1994]. When the waters of the outer Bay of Fundy are thus stratified, the waters comprising the EMCC come more directly from the southwest Scotian Shelf.

The existence of cold plumes separating from the coastal current in eastern Maine and extending off shelf into the interior Gulf of Maine have been reported by many previous workers [e.g., Fish and Johnson, 1937; Brooks and Townsend, 1989; Bisagni et al., 1996], but little information has previously been reported about variability of the location of the plume separation. Brooks and Townsend [1989] reported the location of plume separation to move approximately $50 \mathrm{~km}$ westward toward Penobscot Bay over a 3-week period in August 1987. They concluded that the separation point was determined by the slope water distribution that had also migrated westward during this period.

Our survey of 1994 Gulf of Maine AVHRR images shows instances of multiple plumes and documents a seasonal oscillation in the alongshore location from which cold plumes were observed to leave the Maine shelf. The survey showed that the separation point ranged from roughly $100 \mathrm{~km}$ east to $100 \mathrm{~km}$ west of Mount Desert Island from spring through summer and then retreated eastward during the fall. Preliminary numerical modeling results [Xue et al., 1996] suggest that this east-west seasonal oscillation may be an annual occurrence. The fact that Brooks and Townsend [1989] found the separation point still east of Mount Desert in August 1987 is very likely because 1987 was an anomalous year. Brown and Irish [1992] reported that the geostrophic transport in the gulf was anticyclonic until mid-July 1987 and only later in the summer reverted to the typical cyclonic circulation pattern. On the basis of these admittedly thin lines of evidence and the numerical experiments by Lynch et al. [1997], we hypothesize that the location from which plumes erupt from the EMCC may depend upon modulation of topographic steering by seasonal baroclinic pressure fields.

Two cold water surface plumes extending off shelf from the EMCC are prominent features of the May 11 AVHRR image (Plate 1). A hydrographic section through these features suggests that the plume south of Penobscot Bay observed in this study was merely a near-surface feature associated with the local outflow of the Penobscot River that was unrelated to any offshoots 


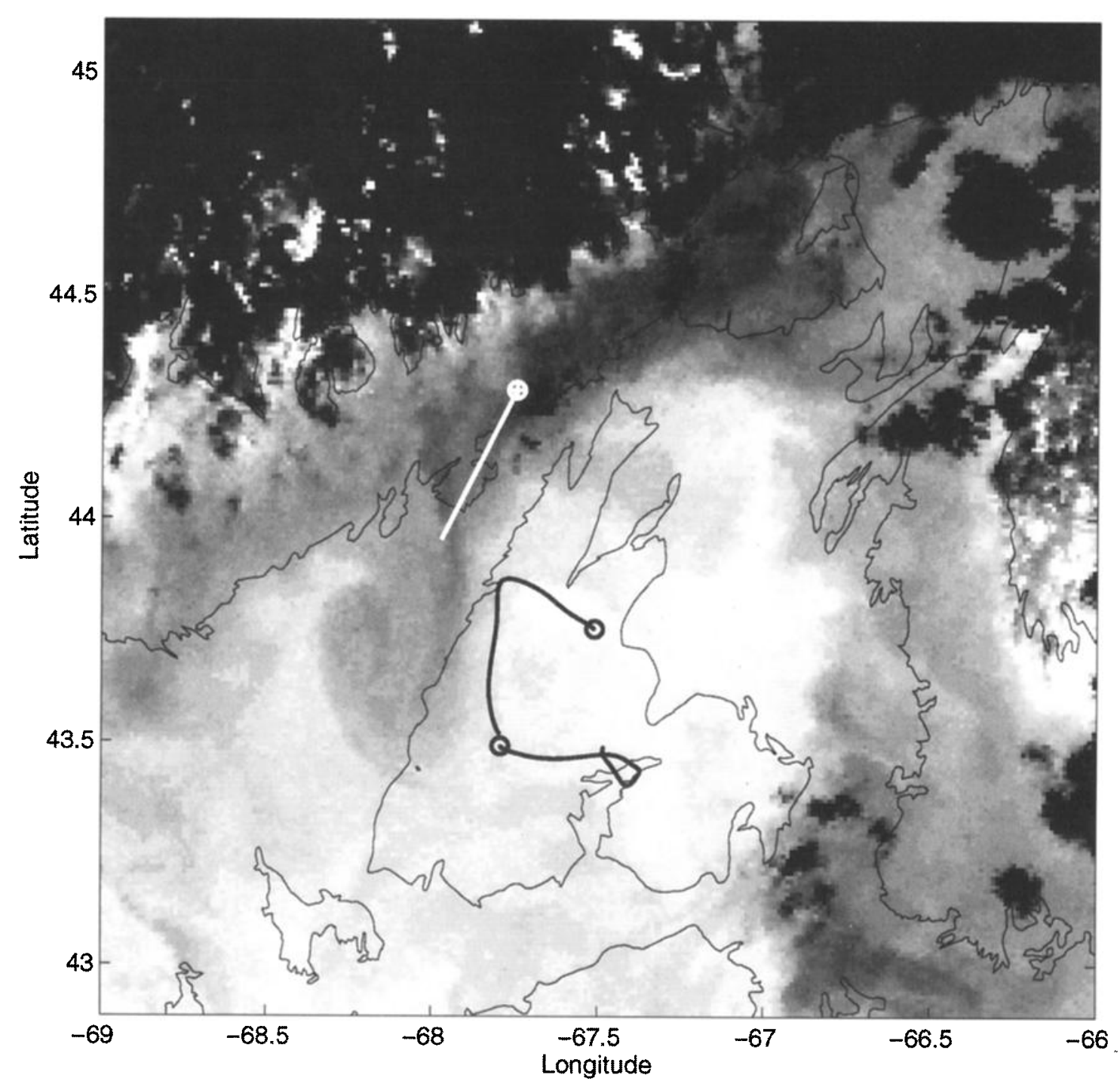

Figure 8. A composite showing an SST image of the plume half a day later than the image shown in Figure 2. Superimposed on the image (in white) is the near-surface current vector (speed of $0.23 \mathrm{~m} \mathrm{~s}^{-1}$ ) at mooring M1 averaged over the day of the image. Also shown (in black) are drifter tracks of two $40 \mathrm{~m}$ drifters released in Jordan Basin. The black circled positions indicate the locations of two drifters approximately 24 hours prior to the SST image. The lines extending from the circles show the drifter positions for the succeeding 7 days. Together, the two drifters show a cyclonic displacement around the central Jordan Basin.

of the EMCC. This observation calls into question the commonly held view that the EMCC routinely turns offshore at Penobscot Bay. In contrast, the cold feature turning offshore south of Schoodic Point is seen in the hydrographic data to be a major offshore branch of the coastal current that extends to a depth of roughly 100 m. The SST pattern implies anticyclonic vorticity, and geostrophic calculations confirm that the distal end of this plume forms an anticyclonic eddy or meander with near-surface flow (relative to a $140 \mathrm{~m}$ reference level) exceeding $0.3 \mathrm{~m} \mathrm{~s}^{-1}$. It is notable that the cold core of the plume occupies a depression or valley in the underlying slope water topography. The fact that slope water is found on either side of the plume argues that the plume is an offshore intrusion of the coastal current that depressed the local slope water topography rather than being drawn offshore and steered along the edge of the slope water dome as suggested by Brooks and Townsend [1989].

Although it is not possible based on existing data to rigorously discuss the dynamics of the separation and adjustment of plumes erupting from the EMCC, it may be useful to interpret the kinematic observations from this study within a dynamical context. The plume illustrated in Plate 1 exhibited a strong anticyclonic vorticity on its downcoast side, thus forming an eddy or meander near its distal end. We speculate that this anticyclonic vorticity arises during a Rossby adjustment 


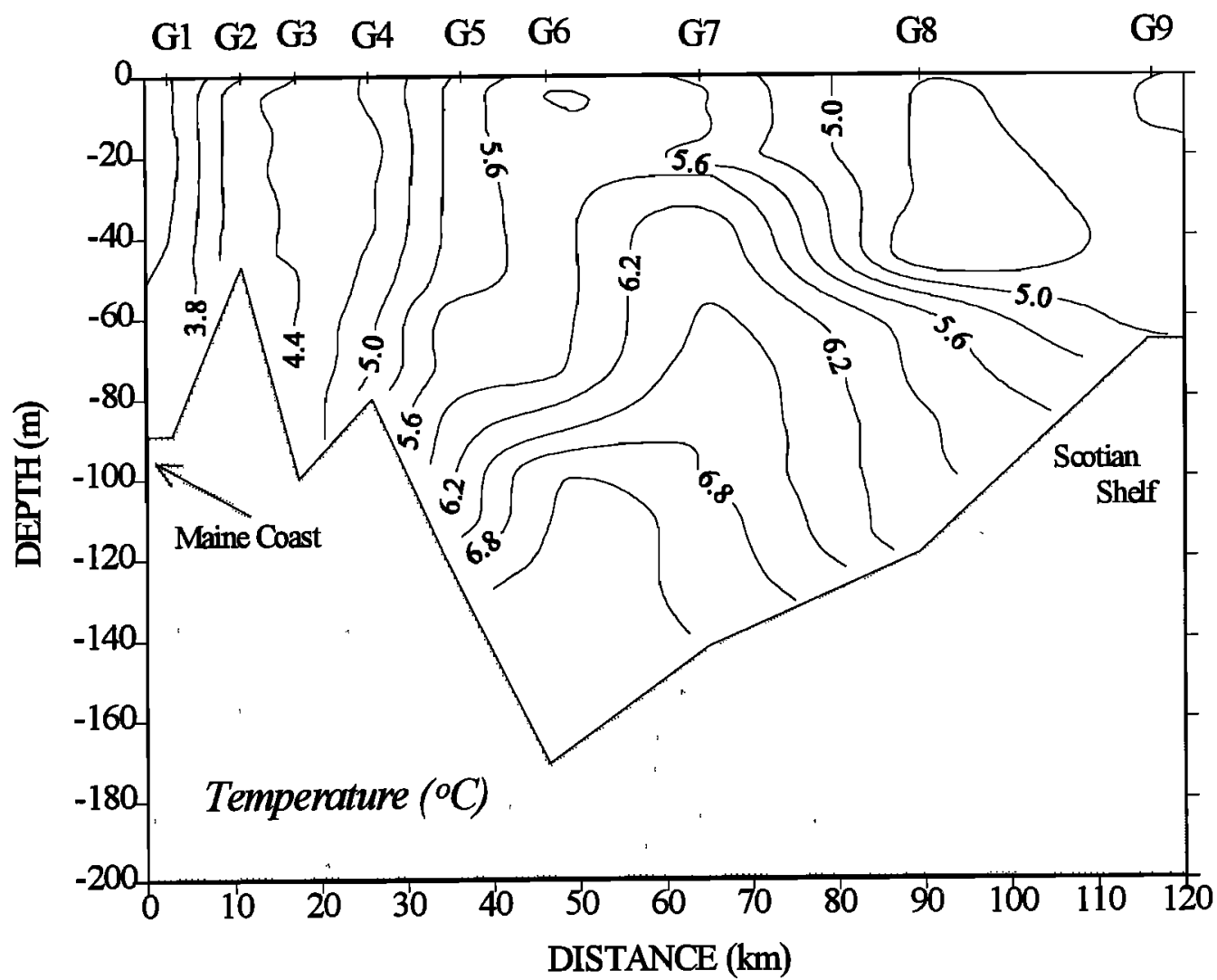

Figure 9a. Temperature distributions along transect 3 from the eastern Maine coast, across the Fundy Channel, to the gulf coast of Nova Scotia. There is a retrograde front between G7 and G8 separating a relatively homogeneous mass of Scotian Shelf Water from the warmer saltier waters in the Fundy Channel. On the Maine side of the transect, the waters over the shelf are very well-mixed vertically. While the salinity values are similar on the Maine and Nova Scotian sides, the waters in eastern Maine are significantly colder.

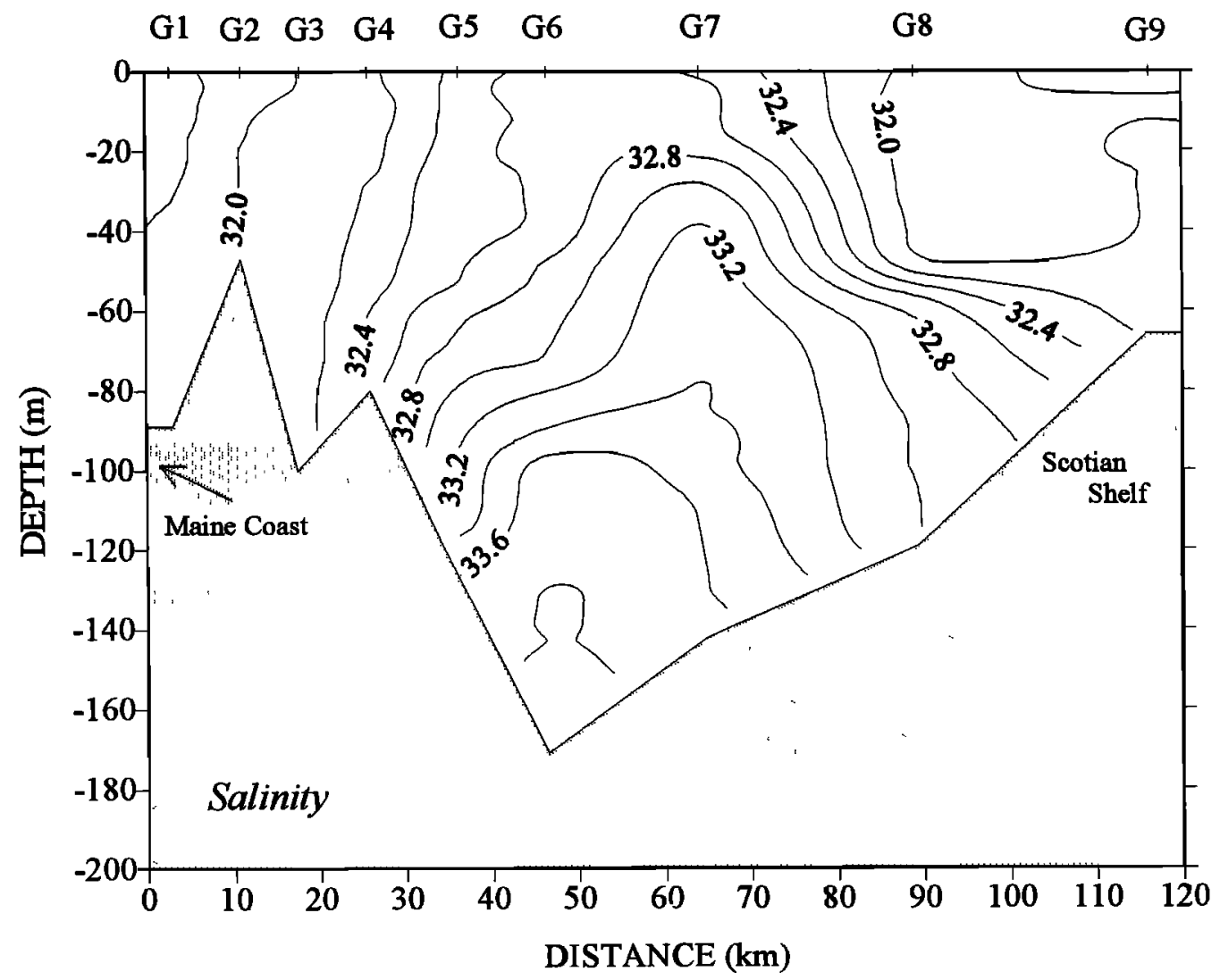

Figure 9b. Same as Figure 9a, but for salinity. 
process [cf. Gill, 1982] as the elevated sea level associated with the coastal current relaxes toward ambient interior gulf levels. Thus what may have begun as an instability or transient offshore turning of the coastal current would result in a relatively stable feature through the process of geostrophic adjustment.

While many of the offshore extensions of the EMCC display anticyclonic vorticity consistent with the geostrophic adjustment mechanism, others (particularly those occurring in the vicinity of Penobscot Bay and points west) show an overall cyclonic pattern. For these offshore SST features, which generally occur after the spring freshet, we speculate that the Rossby adjustment process may have been reduced to secondary importance by the slower flow and the associated lower coastal setup or by the blocking influence of estuarine plumes from the Kennebec and Penobscot Rivers. In these cases the larger-scale processes associated with the offshore cyclonic gyre may more strongly determine the curvature of the plumes emanating from the shelf region.

The combination of SST imagery and hydrographic data leads us to conclude that the majority of the coastal current water in the May 11 plume was involved in the anticyclonic eddy or meander. While drifter trajectories indicate that a portion of the northeast (upcoast) side of the plume did become entrained in a cyclonic recirculation of the Jordan Basin Gyre, the higher salinity values observed in the cold core of the gyre argue persuasively that the plume waters thus entrained made up a small fraction of the waters participating in the cyclonic circulation in the Jordan Basin.

The data reported in this study support earlier work [Townsend et al., 1987] suggesting that the transport of the EMCC represents a very significant horizontal flux of new nitrogen in the Gulf of Maine. The off-shelf nitrate transport associated with the plume in this study was calculated to be approximately $5 \mathrm{~kg} \mathrm{~N} \mathrm{~s}^{-1}$. This figure is of the same order as the total nitrate flux into the gulf through the Northeast Channel estimated by Schlitz and Cohen [1984]. These calculations show that the episodic offshore extensions of the EMCC can represent an important source of nutrients to the interior Gulf of Maine. Given that timescales associated with plume are of the order of a week or two, the precise trajectory of the plume may exert strong local influence on the quantity and quality of primary production in the eastern and central gulf.

Acknowledgments. N.R.P. is deeply indebted to G.T. Csanady for years of patient guidance and innumerable scientific and philosophical discussions. I have attempted to pass on some of his wisdom to my own students, several of whom appear as coauthors of this manuscript. This work was supported by the NOAA Gulf of Maine Regional Marine Research Program project GMR-02 and NSF grant OCE9319843. Ken Morey and Dan Howard assisted in mooring deployments, and Laurie M. Stearns participated in hydrographic cruises and produced the majority of the figures. We are indebted to an anonymous reviewer whose comments clarified the interpretation of the surface temperature pattern associated with the outflow from the Penobscot River Estuary. The SST images were produced by NOAA Coastwatch and were obtained via the internet from the University of New Hampshire's REDIMS database.

\section{References}

Bigelow, H. B., Plankton of the offshore waters of the Gulf of Maine, Fish. Bull., 40, 1-509, 1926.

Bigelow, H. B., Physical oceanography of the Gulf of Maine, Fish. Bull., 40, 511-1027, 1927.

Bisagni, J. J., D. J. Gifford, and C. M. Ruhsam, The spatial and temporal distribution of the Maine Coastal Current during 1982, Cont. Shelf Res., 16, 1-24, 1996.

Brooks, D. A., Vernal circulation in the Gulf of Maine, $J$. Geophys. Res., 9O(C5), 4687-4705, 1985.

Brooks, D. A., A model study of the buoyancy-driven in the Gulf of Maine, J. Phys. Oceanogr., 24, 2387-2412, 1994.

Brooks, D. A., and E. M. Gottlieb, Springtime hydrographic surveys in the Gulf of Maine: 1982, 1983, and 1984, Tech. Rep. 85-3-T, 234 pp., Texas A\&M Univ., College Station, 1985.

Brooks, D. A., and D. W. Townsend, Variability of the coastal current and nutrient pathways in the eastern Gulf of Maine, J. Mar. Res., 47, 303-321, 1989.

Brown, W. S., and J. D. Irish, The annual evolution of geostrophic flow in the Gulf of Maine: 1986-1987, J. Phys. Oceanogr., 22, 445-473, 1992.

Brown, W. S., and J. D. Irish, The annual variation of water mass structure in the Gulf of Maine: 1986-1987, J. Mar. Res., 51, 53-107, 1993.

Fish, C. J., and M. W. Johnson, The biology of the zooplankton population in the Bay of Fundy and Gulf of Maine with special reference to production and distribution, J. Biol. Board Can., 3, 189-322. 1937.

Garrett, C. J., J. R. Keely, and D. A. Greenberg, Tidal mixing versus thermal stratification in the Bay of Fundy and Gulf of Maine, Atmos. Ocean, 16, 403-423, 1978.

Gill, A. E., Atmosphere-Ocean Dynamics, 662 pp., Academic, San Diego, Calif., 1982.

Hetland, R. D., The evolution of the vernal circulation in the eastern Gulf of Maine: 1994, M.S. thesis, 82 pp., Univ. of Maine, Orono, 1996.

Hopkins, T. S., and N. Garfield III, Gulf of Maine Intermediate Water, J. Mar. Res., 37, 103-139, 1979.

Huntley, M., and C. Boyd, Food-limited growth of marine zooplankton, Amer. Nat., 124, 455-478, 1984.

Loder, J. W., Topographic rectification of tidal currents on the sides of Georges Bank, J. Phys. Oceangr., 10, 1399$1416,1980$.

Loder, J. W., and D. A. Greenberg, Predicted positions of tidal fronts in the Gulf of Maine region, Cont. Shelf Res., $6,397-414,1986$.

Lynch, D. R., J. T. Ip, C. E. Naimie, and F. E. Werner, Comprehensive coastal circulation model with application to the Gulf of Maine, Cont. Shelf Res., 16, 875-906, 1996.

Lynch, D. R., M. J. Holbrook, and C. E. Naimie, The Maine coastal current: Spring climatological circulation, Cont. Shelf Res., 17, 605-634, 1997.

Parsons, T. R., Y. Maita, and C. M. Lalli, A Manual of Chemical and Biological Methods of Seawater Analysis, 173 pp., Pergamon, Tarrytown, N.Y., 1984.

Pettigrew, N. R., and R. D. Hetland, The cyclonic circulation of the eastern Gulf of Maine, paper presented at Oceanographic Society, Newport, R.I., 1995.

Pettigrew, N.R., and S. P. Murray, The coastal boundary layer and inner shelf, in Baroclinic Processes on Continental Shelves, Coastal Estuarine Sci., vol. 3, edited by 
C. N. K. Mooers, pp. 95-108, AGU, Washington, D.C., 1986.

Ramp, S. R., R. J. Schlitz, and W. R. Wright, The deep flow through the Northeast Channel, Gulf of Maine, J. Phys. Oceanogr., 15, 1790-1808, 1985.

Schlitz, R. J., and E. B. Cohen, A nitrogen budget for the Gulf of Maine and Georges Bank, Biol. Oceanogr., 3, 203222, 1984.

Smith, P.C., Mean and seasonal circulation off southwest Nova Scotia, J. Phys. Oceanogr., 13, 1034-1054, 1983.

Townsend, D. W., J. P. Christensen, D. K. Stevenson, J. J. Graham, and S. B. Chenoweth, The importance of a plume of tidally-mixed water to the biological oceanography of the Gulf of Maine, J. Mar. Res., 45, 515-529, 1987.

Townsend, D. W., J. F. Brown, and B. E. Cucci, Oceanographic conditions during spring on Georges Bank and in the Gulf Maine; Results of R/V Columbus Iselin Cruises: 20-29 April 1993, 17-26 May 1993, 7-5 April 1994, 12-20
May 1994, Tech. Rep. 9401, 157 pp., Dep. of Oceanogr., Univ. of Maine, Orono, 1994.

Xue, H., F. Chai, and N. Pettigrew, Numerical simulations of the Gulf of Maine seasonal circulations using the Princeton Ocean Model, paper presented at Gulf of Maine Ecosystem Dynamics: A Scientific Symposium and Workshop, Regional Association for Research on the Gulf of Maine, St. Andrews, New Brunswick, Canada, Sept. 16$20,1996$.

P. J. Brickley, R. D. Hetland, N. R. Pettigrew, D. W. Townsend, J. P. Wallinga, and H. Xue, School of Marine Sciences, University of Maine, Orono, ME 04469-5741. (email: nealp@maine.edu)

(Received April 1, 1996; revised October 16, 1996; accepted January 2, 1997.) 